\title{
Small Scale Solar Cooling Unit in Climate Conditions of Latvia: Environmental and Economical Aspects
}

\author{
Dzintars Jaunzems, Institute of Energy Systems and Environment, Riga Technical University, Ivars Veidenbergs, \\ Institute of Energy Systems and Environment, Riga Technical University
}

\begin{abstract}
The paper contributes to the analyses from the environmental and economical point of view of small scale solar cooling system in climate conditions of Latvia. Cost analyses show that buildings with a higher cooling load and full load hours have lower costs. For high internal gains, cooling costs are around $1,7 € / \mathrm{kWh}$ and $2,5 € / \mathrm{kWh}$ for buildings with lower internal gains. Despite the fact that solar cooling systems have significant potential to reduce $\mathrm{CO}_{2}$ emissions due to a reduction of electricity consumption, the economic feasibility and attractiveness of solar cooling system is still low.
\end{abstract}

Keywords - absorption chiller, cooling load, reduction of $\mathrm{CO}_{2}$, solar collector, solar cooling.

\section{INTRODUCTION}

It is estimated that the building sector (residential and tertiary) accounts for about $40 \%$ of energy consumption worldwide. About one third of the consumption is related to cooling or air conditioning in buildings, especially in southern climates. $80 \%$ of the greenhouse gas emissions in Europe still come from the energy sector [1]. The demand for building cooling has been increasing in the past few years and will continue to increase. There are several reasons for such a forecast: more and more popular tendency of modern architecture to use glass facade surface areas, higher demand for comfort, quantitative increase of office and service buildings, increasing number of electric appliances and, in one word, expected economic growth [1,3]. The presence of solar irradiation and the need for cooling practically occur simultaneously, which makes solar cooling an attractive alternative to conventional (basically electric driven) cooling in modern buildings [4]. All that implies energy, economic and environmental consequences because solar cooling systems use less primary energy than conventional cooling systems thus emit less $\mathrm{CO}_{2}$ and have less impact on the environment [5].

Compared with the traditional compressor-based air conditioner, the solar cooling system can save up to $80 \%$ electric energy when providing the same cooling capacity for office buildings. Hence, the system offers a good energy conservation method for office buildings [6, 7, 8]. Solar fractions therefore need to be higher than about $50 \%$ to start saving primary energy [9].

Absorption is the most commonly used type of thermally driven cooling unit. Approximately $60 \%$ of these systems use absorption chillers, $11 \%$ adsorption chillers, and $29 \%$ use open systems (desiccant and liquid sorption systems). The solar cooling capacity is assisted by solar flat plate collectors or solar vacuum tube collectors $[10,11]$ or by waste heat. For the often used single effect cooling machines, the ratio of cold production to input heat (COP) is in the range of 0.5-0.8, while electrically driven compression chillers today work at COPs around 3.0 or higher $[12,13]$.

For much of Europe, increases in cooling energy demand due to global warming will be outweighed by reductions in the need for heating energy [14]. But solar cooling systems are still expensive. Investment costs vary between 3200-5100 € per kilowatt of cooling output for small scale systems $[15,16]$. The reasons for this are: lack of standardization of the system configurations and mass production, as well as lack of practical experience.

The cooling load of a building depends on climate conditions, thermophysical properties and parameters (insulation thickness, thermal conductivity etc.) of the building envelope, and internal gains (inhabitants, electrical appliances etc.) [17-25]. That is why it is necessary to consider, on one hand, energy efficiency measures and on the other hand - the appropriate and environmentally friendly cooling technologies to cover existing cooling loads of buildings. A long runtime of a solar cooling system have several advantages when viewed from the perspective of environmental aspects as well as from economical aspects.

\section{SCOPE AND METHODOLOGY OF THE PAPER}

The paper analyses the environmental and economical aspects of small scale solar cooling system in climate conditions of Latvia. The goals are to specify the associated costs and calculate the reduction of $\mathrm{CO}_{2}$ in comparison with a traditional cooling unit to cover cooling load of the building.

To evaluate environmental and economical aspects of small scale solar cooling systems, cooling load files were produced on an hourly basis with a developed cooling load calculation model CooL for a small existing building with about $520 \mathrm{~m}^{2}$ total cooled area, $120 \mathrm{~m}^{2}$ total windows area $\left(67 \mathrm{~m}^{2}\right.$ old wooden frame and $53 \mathrm{~m}^{2}$ plastic frame windows), and $346 \mathrm{~m}^{2}$ façade area. The air exchange rate was $0.545 \mathrm{~h}^{-1}$. Specific heat losses via enclosed constructions of building were 1072.2 $\mathrm{W} / \mathrm{K}$, but total specific heat losses of building included ventilation, doors, roof, walls and windows were $1509.8 \mathrm{~W} / \mathrm{K}$. [26]. The building internal gain and characteristics of the building envelope were varied to analyze the economical and 
environmental aspects of a solar cooling system. The building internal gain include all heat from electrical equipment and inhabitants. To cover the cooling load of the building for a solar cooling system, a commercially available absorbtion chiller with 15 or $25 \mathrm{~kW}$ nominal cooling power was chosen.

The cooling load of the absorption chiller was chosen to maintain internal room temperature levels at a given set point of $24^{\circ} \mathrm{C}$ for all operation hours.

\section{EXPECTED BUILDING COOLING LOAD DETERMINATION}

To evaluate the environmental aspects and economic performance of solar cooling systems under varying conditions, different building cooling load files were produced with the calculation tool CooL.

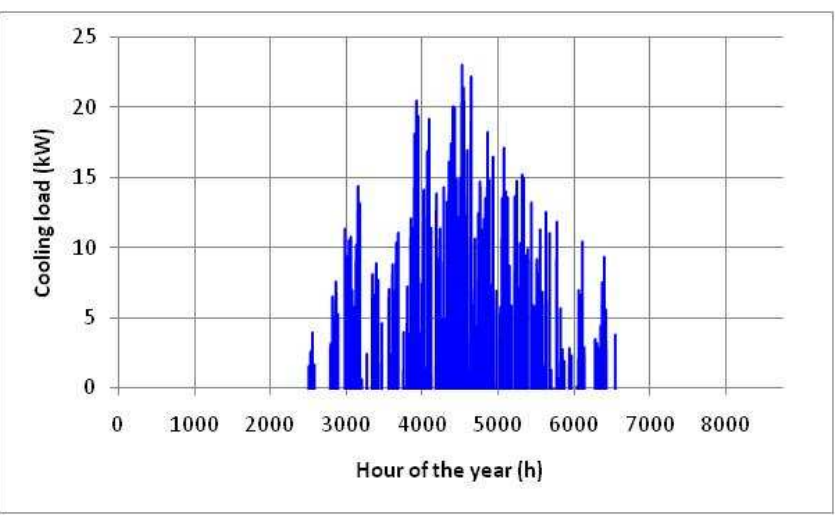

Fig. 1. Existing building with high internal loads (Build1_High).

The air exchange rates were held constant at $0.5 \mathrm{~h}^{-1}$ for the building throughout the year. Surplus heat from the building analyzed was removed by a water-based distribution system, which was fed cold water from the cooling unit, to maintain a set internal temperature.

The power of the absorption cooling unit was chosen to keep the internal temperature levels below a set point of $24^{\circ} \mathrm{C}$ for all operation hours (see Table II).

To evaluate the economic and environmental performance of the solar cooling system, four different energy consumption and cooling energy demand profiles were produced for the existing building using the calculation tool CooL:
- existing building with low internal gains of $4 \mathrm{~W} / \mathrm{m}^{2}$ - acronym Build1_Low,

- existing building with high internal gains of 20 W/m $\mathrm{m}^{2}$ - acronym Build1_High (see Fig. 1),

- building after implementation of energy efficiency measures with low internal gains of $4 \mathrm{~W} / \mathrm{m}^{2}-$ acronym Build2_Low (see Fig. 2),

- building after implementation of energy efficiency measures with high internal gains of $20 \mathrm{~W} / \mathrm{m}^{2}-$ acronym Build2_High,

- reference building in Stuttgart (Germany) with low internal gains of $4 \mathrm{~W} / \mathrm{m}^{2}$ - acronym Build3_Ref.

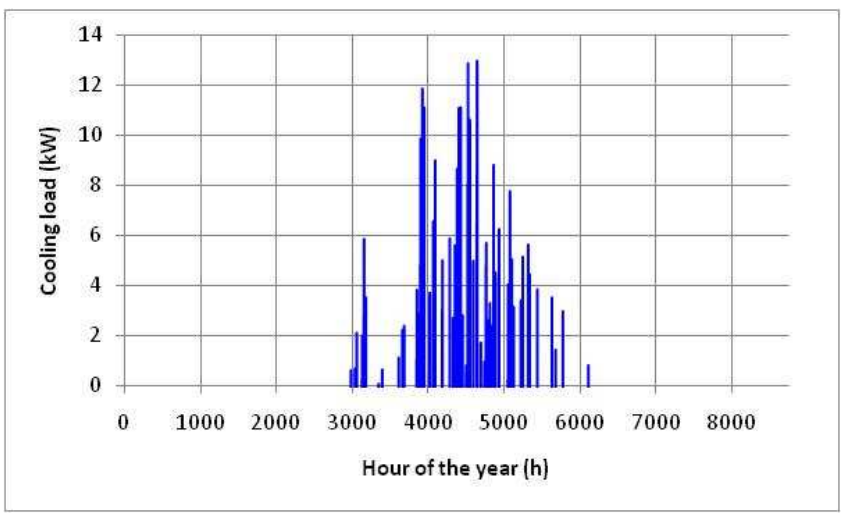

Fig. 2. Building with low internal loads and improved efficiency (Build2_Low).

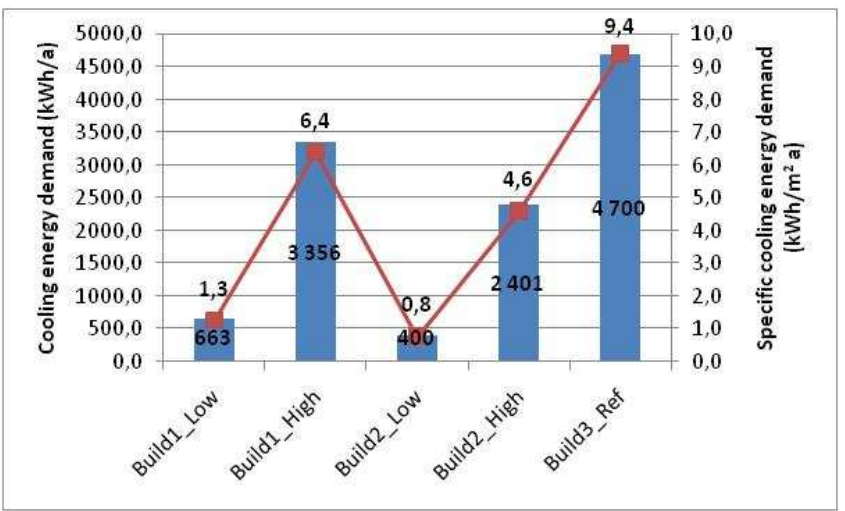

Fig. 3. Specific and total annaul cooling energy demand for the building with different internal gains.

TABLE I

THE SPECIFICATIONS AND PARAMETERS OF THE BUILDINGS FOR COOLING LOAD CALCULATIONS

\begin{tabular}{|l|l|l|l|l|l|}
\hline $\begin{array}{l}\text { Building } \\
\text { case }\end{array}$ & $\begin{array}{l}\text { Internal } \\
\text { gains } \\
\left(\mathrm{W} / \mathrm{m}^{2}\right)\end{array}$ & $\begin{array}{l}\text { Overall heat transfer } \\
\text { coefficient of the walls, } \mathrm{U}_{\text {wall }} \\
\left(\mathrm{W} / \mathrm{m}^{2} \mathrm{~K}\right)\end{array}$ & $\begin{array}{l}\text { Overall heat transfer } \\
\text { coefficient of the windows, } \\
\mathrm{U}_{\text {win }}\left(\mathrm{W} / \mathrm{m}^{2} \mathrm{~K}\right)\end{array}$ & $\begin{array}{l}\text { Overall heat transfer } \\
\text { coefficient of the roof, } \mathrm{U}_{\text {roof }} \\
\left(\mathrm{W} / \mathrm{m}^{2} \mathrm{~K}\right)\end{array}$ & $\begin{array}{l}\text { Overall heat transfer } \\
\text { coefficient of the floor } \mathrm{U}_{\text {roof }} \\
\left(\mathrm{W} / \mathrm{m}^{2} \mathrm{~K}\right)\end{array}$ \\
\hline Build1_Low & 4 & 1.07 & $1.9-2.38$ & 0.68 & $0.67-1.33$ \\
\hline Build1_High & 20 & 1.07 & $1.9-2.38$ & 0.68 & $0.67-1.33$ \\
\hline Build2_Low & 4 & 0.4 & 1.8 & 0.35 & 0.45 \\
\hline Build2_High & 20 & 0.4 & 1.8 & 0.35 & 0.45 \\
\hline
\end{tabular}

The cooling energy demand of building is between 400 $\mathrm{kWh}$ in the building after implementation of energy efficiency measures with low internal gains up to $3400 \mathrm{kWh}$ in the existing building with high internal gains (see Fig. 3). A wide range of specific cooling energy demands are covered, ranging from about $0.8 \mathrm{kWh} / \mathrm{m}^{2}$ annual for a building after energy 
efficiency measures with low internal gains up to $6.4 \mathrm{kWh} / \mathrm{m}^{2}$ per annum for the existing building with high internal gains.

The specifications and parameters for the existing building and building after energy efficiency measures are summarized in Table I.

\section{SOLAR COOLING SYSTEM DESCRIPTION AND CONFIGURATION}

For an annual cooling energy demand from 400 up to 3400 $\mathrm{kWh}$ and average COP of 0.55 the cooling unit whole system requires from 720 to $6100 \mathrm{kWh}$ of heating energy. The design generator entry temperature is $65^{\circ} \mathrm{C}$ at an absorber cooling entry temperature of $26^{\circ} \mathrm{C}$ and an evaporator entry of $12^{\circ} \mathrm{C}$ and exit of $6^{\circ} \mathrm{C}$. To achieve a solar fraction of at least $60 \%$ for the given cooling load profiles, a collector surface area of 2 to $26 \mathrm{~m}^{2}$ and a storage tank volume of 0.2 up to $2.1 \mathrm{~m}^{3}$ is required, if the generator is always operated at a mean temperature of $65^{\circ} \mathrm{C}$.

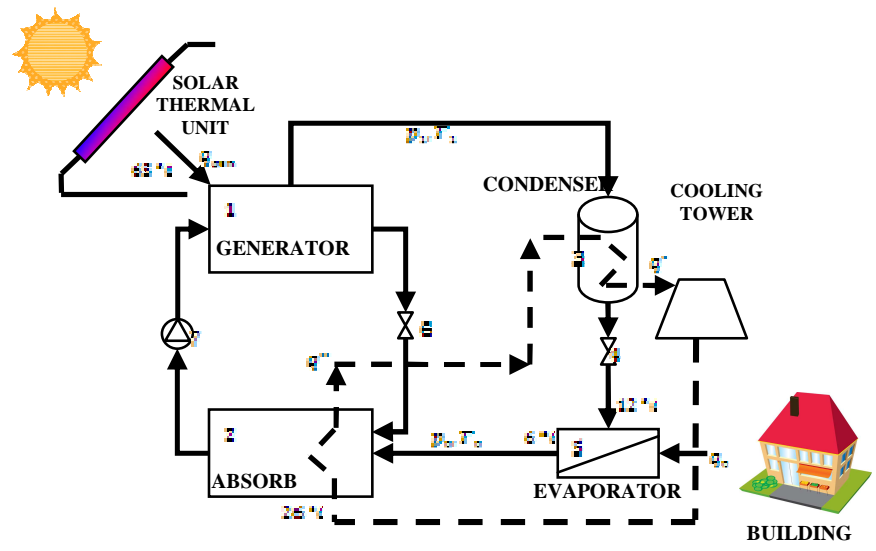

Fig. 4. Schematic view of the solar single effect absorbtion cooling system.
For the constant generator inlet temperature level of $65^{\circ} \mathrm{C}$, the specific collector yield is in the range from 237 up to 370 $\mathrm{kWh} / \mathrm{m}^{2}$ per year for an annual solar irradiance of 1080 $\mathrm{kWh} / \mathrm{m}^{2}$. The solar thermal system efficiency was assumed to be $22 \%$ (for flat plate solar collectors) and $34 \%$ (for vacuum solar collectors), respectively.

The size of the solar thermal system is based on the capacity of the absorbtion cooling unit and available solar irradiation. The solar cooling system design values for the different buildings are summarized in Table II. A schematic view of the solar single effect absorption cooling system is shown in Figure 4.

\section{A. Solar thermal system}

The solar cooling system model includes a solar collector (flat plate and vacuum tube), a stratified storage tank, an absorbtion chiller, a control unit, and a back-up heater. A solar collector is modeled using the steady-state solar collector equation with an optical efficiency $\eta_{0}$ and the two linear and quadratic heat loss coefficients $a_{1}$ and $a_{2}$. The flat plate and vacuum tube solar collectors available on the market were used with optical efficiency $\eta_{0}$ of 0.82 and 0.78 , with $a_{1}$ at 3.61 and $1.48 \mathrm{~W} / \mathrm{m}^{2} \mathrm{~K}$ and $\mathrm{a}_{2}$ at 0.014 and $0.008 \mathrm{~W} / \mathrm{m}^{2} \mathrm{~K}^{2}$, respectively.

\section{B. Absorption cooling unit}

From the different types of absorption cooling machines, the water-cooled single effect model is that which is most commonly used for cooling applications for buildings.

The capacity of the absorption cooling unit depends on cooling load of the building. In turn, the cooling load of the building depends on ambient temperature, solar irradiation, internal gains, and thermal characteristics of building. Chosen absorbtion chiller working pair is $\mathrm{LiBr}-\mathrm{H}_{2} \mathrm{O}$ with a design generator entry temperature of $65^{\circ} \mathrm{C}$ at an absorber cooling water entry temperature of $26^{\circ} \mathrm{C}$ and an evaporator entry of $12^{\circ} \mathrm{C}$ and exit of $6^{\circ} \mathrm{C}$.

TABLE II

SUMMARY OF SOLAR COOLING SYSTEM DESIGN VALUES FOR THE DIFFERENT BUILDINGS

\begin{tabular}{|c|c|c|c|c|c|c|c|c|}
\hline \multirow[b]{2}{*}{ Building case } & \multirow{2}{*}{$\begin{array}{l}\text { Full cooling } \\
\text { load hours } \\
\text { (h) }\end{array}$} & \multirow{2}{*}{$\begin{array}{l}\text { Cooling } \\
\text { energy } \\
\text { demand } \\
(\mathrm{kWh})\end{array}$} & \multirow[b]{2}{*}{$\begin{array}{l}\text { Abs. chiller } \\
\text { power }(\mathrm{kW})\end{array}$} & \multicolumn{2}{|c|}{ Collector area $\left(\mathrm{m}^{2}\right)$} & \multicolumn{2}{|c|}{ Storage volume $\left(\mathrm{m}^{3}\right)$} & \multirow[b]{2}{*}{$\begin{array}{l}\text { Average COP of } \\
\text { absorption chiller }\end{array}$} \\
\hline & & & & Flat plate & $\begin{array}{l}\text { Vacuum } \\
\text { tube }\end{array}$ & Flat plate & $\begin{array}{l}\text { Vacuum } \\
\text { tube }\end{array}$ & \\
\hline Build1_Low & 169 & 662.6 & 15 & 5 & 3 & 0.4 & 0.3 & 0.55 \\
\hline Build1_High & 541 & 3355.9 & 25 & 26 & 17 & 2.1 & 1.3 & 0.55 \\
\hline Build2_Low & 102 & 399.6 & 15 & 3 & 2 & 0.2 & 0.2 & 0.55 \\
\hline Build2_High & 379 & 2400.9 & 25 & 18 & 12 & 1.5 & 1.0 & 0.55 \\
\hline
\end{tabular}

\section{V.ECONOMICAL ANALYSIS}

To plan and design solar cooling systems, economic considerations and analyses make the basis for decision makers.

The costs in energy economics can be divided into three categories:
- capital costs, which contain the initial investment including installation,

- operating costs for maintenance and system operation,

- costs for energy and other material inputs into the system. 
The total costs per $\mathrm{kWh}$ of cold produced $\mathrm{C}_{\text {sum }}$ are obtained by summing the chiller cost $C_{\text {chiller }}$ to the solar thermal system costs $\mathrm{C}_{\text {solar }}$, the auxiliary heating costs $\mathrm{C}_{\text {heating, }}$, and costs for the cooling water production $\mathrm{C}_{\text {cool }}$. The costs for heating have to be divided by the average COP of the system to refer the cost per $\mathrm{kWh}$ heat to the cold production and multiplied by the solar fraction for the respective contributions of solar and auxiliary heating. For the cooling water, costs per $\mathrm{kWh}$ of cooling water were taken from the literature review $[12,27]$ and referred to the $\mathrm{kWh}$ of cold by multiplication with $(1+(1 / \mathrm{COP}))$ for removing the evaporator heat (factor 1) and the generator heat with a factor $1 / \mathrm{COP}$.

$$
C_{\text {sum }}=C_{\text {chiller }}+\frac{s_{f} C_{\text {solar }}}{C O P}+\frac{\left(1-s_{f}\right) C_{\text {heating }}}{C O P}+C_{\text {cool }}\left(1+\frac{1}{C O P}\right)
$$

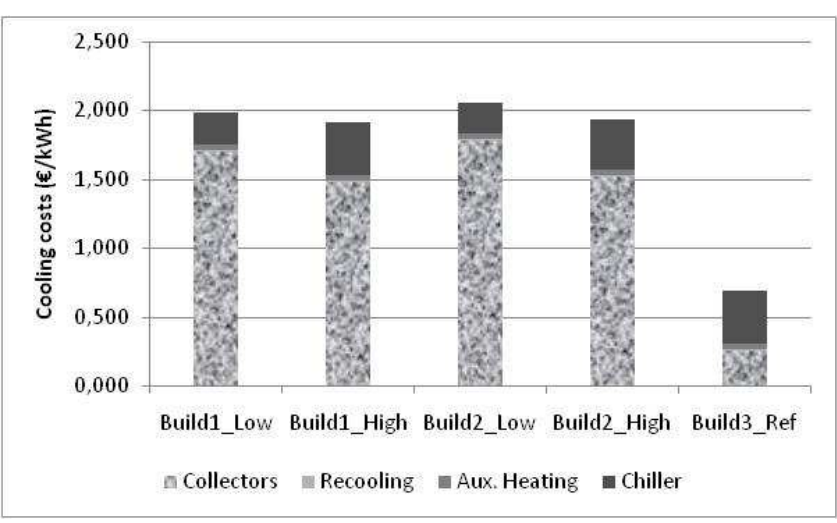

Fig. 5. Cooling costs per kWh of cold for building with different internal gains.

A value for $C_{\text {cool }}$ of $0.009 € / \mathrm{kWh}$ cooling water was used and auxiliary heating costs $C_{\text {heating }}$ were set to $0.04 € / \mathrm{kWh}$ heat.

To evaluate the benefits of a solar cooling system in comparison with an electrically driven cooling system, two different price scenarios were considered:

- electricity price increase at the same rate as the social discount rate, that is $3.5 \%$;

- electricity price increase at the current rate, which is $10 \%$.

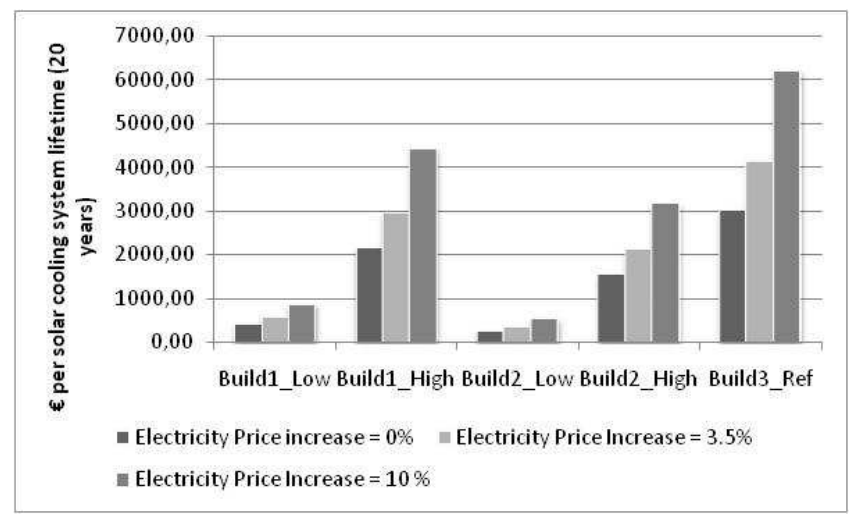

Fig. 6. Benefits from solar cooling system compared with electrically driven cooling system for different electricity price increase scenarios.

\section{ENVIRONMENTAL ANALYSES}

The environmental analysis of the solar cooling system comprises an analysis of green house gasses emissions, ozone depletion substance emissions and water consumption and pollution. For its part, the environmental impact of energy use in solar cooling systems can be measured by $\mathrm{kg}$ of greenhouse gases emitted per $\mathrm{kWh}$ of consumed energy $\left(\mathrm{t}_{\mathrm{CO} 2} / \mathrm{kWh}\right)$. The cooling equipment might release greenhouse gases into the atmosphere in two ways:

- Directly: refrigerant may be released into the atmosphere during equipment installation, normal operation, decommissioning, or eventual disposal.

- Indirectly: due to the fact that air-conditioning equipment use electricity (necessary to operate the system) generated from different fossil fuels, nuclear power and water, it releases greenhouse gases.

Direct $\mathrm{CO}_{2}$ emissions were assumed insignificant due to the high quality and security of solar cooling systems manufacturing and installation. Solar thermal systems produce negligible environmental pollution during their manufacture, operation and dismantling. Solar cooling systems have the advantage of using harmless working fluids such as water or solutions of certain salts; they are totally environmentally safe.

The extent of the carbon dioxide emissions for a given carbon content in the fuel and for a given generation efficiency depends primarily on the energy efficiency of the solar cooling equipment.

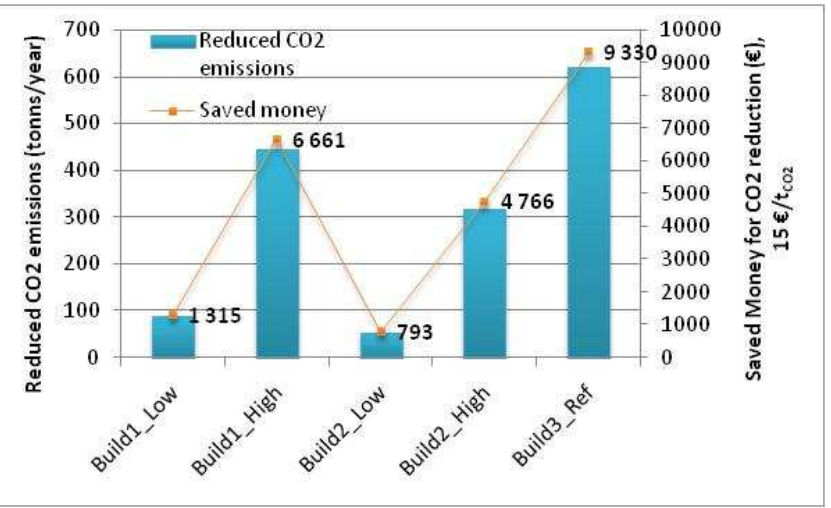

Fig. 7. Reduction of $\mathrm{CO}_{2}$ and potential return of investments due to $\mathrm{CO}_{2}$ trading $\left(15 € / \mathrm{t}_{\mathrm{CO} 2}\right)$.

The amount of generated carbon dioxide is directly proportional to the amount of used energy or, in case of the solar cooling system, reduced electricity consumption to cover cooling load of the building. The analysis that can determine the overall contribution to global warming from energy using equipment over its operating lifetime is the Total Environmental Warming Impact (TEWI) analysis [28]. TEWI is an index that should be used to compare the global warming effects of alternative air-conditioning systems because it includes these contributions from the refrigerant, cooling efficiency, and weight.

A 20-year lifetime was assumed for the solar cooling system. The TEWI factor is expressed in terms of equivalent $\mathrm{kg} \mathrm{CO}_{2}$ direct and indirect emissions. 


$$
\mathrm{TEWI}=T_{\text {directCO2}}+T_{\text {indirectCO2}}
$$

In terms of cost per ton of $\mathrm{CO}_{2}$ saved per year and for the lifetime of the solar cooling system, the results vary depending on the building and on the rate of increase in fuel price (see Table III).

It was assumed that generation of electricity is from gas in condensation mode because it is typical for Latvia. The emission factor was taken $0.365 \mathrm{t}_{\mathrm{CO} 2} / \mathrm{MWh}_{\mathrm{el} .}$.

TABLE III

THE Summary OF ENVIRONMENTAL ANALYSES OF SOLAR COOLING SYSTEM IN DifFERENT BUILDINGS

\begin{tabular}{|c|c|c|c|c|c|c|c|c|}
\hline \multirow{3}{*}{ Building case } & \multicolumn{2}{|c|}{$\begin{array}{l}\text { Reduction of electricity } \\
\text { consumption }\end{array}$} & \multicolumn{2}{|c|}{ Reduction of $\mathrm{CO}_{2}$} & \multicolumn{2}{|c|}{$\begin{array}{l}\text { Reduction of } \mathrm{CO}_{2} \text { per lifetime of } \\
20 \text { years }\left(15 \mathrm{EUR} / \mathrm{t}_{\mathrm{CO} 2}\right)\end{array}$} & \multicolumn{2}{|c|}{$\begin{array}{c}\text { Money savings per lifetime of } 20 \\
\text { years in terms of electricity } \\
\text { consumption }\end{array}$} \\
\hline & \multirow[t]{2}{*}{$(\mathrm{kWh} / \mathrm{a})$} & \multirow[t]{2}{*}{ EUR/a } & \multirow[t]{2}{*}{ (tonnes/a) } & \multirow[t]{2}{*}{ EUR/a } & \multirow[t]{2}{*}{ tones } & \multirow[t]{2}{*}{ EUR } & $\begin{array}{c}\text { Electricity price } \\
\text { increase } 3.5 \%\end{array}$ & $\begin{array}{c}\text { Electricity } \\
\text { price increase } \\
10 \%\end{array}$ \\
\hline & & & & & & & EUR per lifetime & $\begin{array}{l}\text { EUR per } \\
\text { lifetime }\end{array}$ \\
\hline Build1_Low & 220.9 & 21.42 & 87.7 & 1315.17 & 1753.6 & 26,303 & 585.9 & 878.3 \\
\hline Build1_High & 1118.6 & 108.51 & 444.1 & 6661.49 & 8882.0 & 133,230 & 2967.7 & 4448.8 \\
\hline Build2_Low & 133.2 & 12.92 & 52.9 & 793.29 & 1057.7 & 15,866 & 353.4 & 529.8 \\
\hline Build2_High & 800.3 & 77.63 & 317.7 & 4765.70 & 6354.3 & 95,314 & 2123.1 & 3182.7 \\
\hline Build3_Ref & 1566.7 & 151.97 & 622.0 & 9329.50 & $12,439.3$ & 186,590 & 4156.3 & 6230.6 \\
\hline
\end{tabular}

\section{CONCLUSIONS AND DISCUSSION}

Economic and environmental aspects of a solar cooling system in different buildings were analyzed in the paper. An absorption chiller was selected to maintain internal room temperature levels at a given point of $24^{\circ} \mathrm{C}$ for all operation hours. Different cooling load files with low and high internal gains for different building cases were developed using the calculation tool CooL. Analyses showed that in order to achieve a given solar fraction of the total heat demand for cooling mostly different solar collector areas and storage volumes are required, depending on the building load file and chosen collector type/ To achieve a solar fraction of $60 \%$, the required collector surface area is in the range of 3 to $26 \mathrm{~m}^{2}$, however the aperture area is around $1.3 \mathrm{~m}^{2} / \mathrm{kW}$, if the generator is operated at a constant high temperature of $65^{\circ} \mathrm{C}$.

For buildings with different internal gains and envelope characteristics, the required collector area varies by a factor of 4 to get the same solar fraction. The total system costs for commercially available solar cooling systems are between 1.7 and $2.5 € / \mathrm{kWh}$, depending on the cooling load of the building and the chosen collector type. The total costs are dominated by the costs for the solar thermal system and the absorption cooling machine.

It was found that solar cooling systems in climate conditions of Latvia have the potential to reduce $\mathrm{CO}_{2}$ emissions, however the economic feasibility and attractiveness is still low even though the price of electricity may increase even up to $10 \%$ for the solar cooling lifetime.

Solar cooling requires higher investments, but is possible to reduce costs if the solar system is designed for both needs cooling in the summer and heating in the winter.

\section{ACKNOWLEDGMENTS}

This work has been supported by the European Social Fund within the project ,Support for the implementation of doctoral studies at Riga Technical University".

\section{REFERENCES}

1. Greenhouse gas emission trends and projections in Europe 2009. Copenhagen. The European Energy Agency, 2009 - [Accessed 11.06.2010].

http://www.eea.europa.eu/publications/eea_report_2009_9.

2. Papadopoulos A.M., Oxizidis S., Kyriakis N.. Perspectives of Solar Cooling in View of the Developments in the Air-conditioning Sector. Renewable and Sustainable Energy Reviews, 2003, vol. 7, p. 419-438.

3. Marletta L. Air Conditioning Systems from a 2nd Law Perspective. Entropy, 2010, vol. 12, p. 859-877.

4. Syed A. at al. A Novel Experimental Investigation of a Solar Cooling System in Madrid. International Journal of Refrigeration, 2005, vol. 28, p. 859-871.

5. Kima D.S., Infante Ferreira C.A. Solar Refrigeration Options - a Stateof-the-art Review. International journal of refrigeration, 2008, vol. 31, p. 3-15.

6. Guo J., Shen H.G. Modeling Solar-driven Ejector Refrigeration System Offering Air Conditioning for Office Buildings. Energy and Buildings, 2009. vol. 41, p. 175-181.

7. Thomas S., André P. Dynamic Simulation of a Complete Solar Assisted Conditioning System in an Office Building Using TRNSYS. In: The $11^{\text {th }}$ International IBPSA Conference, Glasgow, Scotland, July 27-30, 2009.

8. Verdier I. at al. Feasibility of Integration of Solar Cooling Systems in Existing Buildings: Technical and Economical Results. In: The $3^{\text {rd }}$ International Conference Solar Air-Conditioning. September 30October 2, 2009. Palermo, Sicily, Italy. Abstracts. Regensburg, 2009, p. 102-108.

9. Mendes L.F., Collares-Pereira M., Ziegler F. Supply of Cooling and Heating with Solar Assisted Heat Pumps: an Energetic Approach. International Journal of Refrigeration, 1998. vol. 21, p. 116-125.

10. Sparber W., Napolitano A., Melograno P. Overview on World Wide Installed Solar Cooling Systems. In: The $2^{\text {nd }}$ International Conference Solar Air Conditioning, Tarragona, Spain, 2007.

11. Jakob U. Solar Colling in Europe, In: The SCIG Conference, CSIRO Energy Centre, Newcastle, Australia, 2009.

12. Eicker U., Pietruschka D. Design and Performance of Solar Powered Absorption Cooling Systems in Office Buildings. Energy and Buildings, 2008. vol. 41, p. 81-91.

13. Lazzarin R. M. Solar Cooling Plants: How to Arrange Solar Collectors, Absorption Chillers and the Load. International Journal of Low Carbon Technologies 2007 vol. 2(4), p. 376-390.

14. Aebischer B. at al. Impact of Climate Change on Thermal Comfort, Heating and Cooling Energy Demand in Europe. In: The ECEEE 2007 Summer study, Panel 5, La Colle sur Loup, France, 2007.

15. Jakob U. at al. Effizienter Betrieb solarer Kühlsysteme mittels chillii ${ }^{\circledR}$ System Controller; In: Otti Solarthermie-Symposium, Bad Staffelstein, Duechland, 2009.

16. Jakob U. Perfomance and Costs of Low Capacity Solar Cooling Systems. In: CEP Clean Energy Power - Internationales Symposium 
Solares und Erneuerbares Kühlen, Landesmesse Stuttgart, Stuttgart, Germany, 2009.

17. Kontoleon K.J., D.K. Bikas. Thermal Mass vs. Thermal Response Factors: Determing Optimal Geometrical Properties and Envelope Assemblies of Building Materials. In: The International Conference "Passive and Low Energy Cooling for the Built Environment", Santorini, Greece. Abstracts. Santorini. p. 345-350.

18. Kontoleon K.J., D.K. Bikas. The Effect of South Wall's Outdoor Absorbtion Coefficient on Time Lag, Decrement Factor and Temperature Variation. Energy and Buildings 2007. vol. 39, p. 10111018.

19. Asan H. Numerical Computation of Time Lags and Decrement Factors for Different Building Materials. Building and Environment 2006. vol. 41, p. 615-620.

20. Jaunzems Dz., Veidenbergs I. Influence of Thermo-dynamic Properties and Thermal Inertia of the Building Envelope on Building Cooling Load. In: The $50^{\text {th }}$ International Scientific Conference Environmental and Climate Technologies, Riga, Latvia, 2009.

21. Kossecka E., Kosny J. Relations between Structural and Dynamic Thermal Characteristics of Building Walls. In: The International Symposium of CIB W67 "Energy and Mass flow in the Life cycle of Buildings", Vienna, Austria. Abstracts. Vienna, p. 627-632.

22. Kontoleon K. J., Eumorfopoulou E.A. The influence of Wall Orientation and Exterior Surface Solar Absorptivity on Time Lag and Decrement Factor in the Greek region. Renewable Energy 2008. vol. 33, p. 16521664.

23. Luo C. at al. Time Lags and Decrement Factors under Air-conditioned and Free-floating Conditions for Multi-layer Materials. In: The International Conference "Building Simulations 2007", Bejing, China, 2007. Abstracts. Bejing, p. 95-100.
24. Ulgen K. Experimental and Theoretical Investigation of Effects of Walls Thermophysical Properties on Time Lag and Decrement Factor. Energy and Buildings 2002. vol. 34, p. 273-278.

25. Kossecka E., Kosny J. Influence of Insulation Configuration on Heating and Cooling Loads in a Continuously Used Building. Energy and Building 2002. vol. 34, p. 321-313.

26. Jaunzems D., Veidenbergs I. Development and Verification of Method for Building Cooling Load Calculation for Latvian Climate Conditions. In: The 49th International Scientific Conference Environmental and Climate Technologies, Riga, Latvia, 2008. Abstracts. Riga, p. 120-127.

27. Gassel A. Kraft-Wärme-Kälte-Kopplung und solare Klimatisierung, Ph.D. thesis, TU Dresden, 2004.

28. Burns S. S. at al. Technical and Economic Assessment Of Solar Thermal Absorption Cooling Systems in Small Commercial Buildings. Cogeneration \& Distributed Generation Journal, 2007. vol. 22, Issue 4, p. $45-56$.

Dzintars Jaunzems, M.Sc., Researcher

Riga Technical University, Institute of Energy Systems and Environment

Address: Kronvalda boulv. 1, LV-1010, Riga, Latvia

Phone: +371 67089923, Fax: +371 67089908

e-mail: dzintars.jaunzems@ rtu.lv

Ivars Veidenbergs, Dr.hab.sc.ing., Professor

Riga Technical University, Institute of Energy Systems and Environment

Address: Kronvalda 1, LV1010, Riga, Latvia

Phone: +37167089901

e-mail: ivars.veidenbergs@rtu.lv

Dzintars Jaunzems, Ivars Veidenbergs. Ar saules energijju darbināma aukstuma iekārta Latvijas klimatiskajos apstākḷos: vides un ekonomiskie aspekti Saistī̄ā ar to, ka modernajā ēku arhitektūrā arvien vairāk tiek izmantotas stiklotās ārējās norobežojošas konstrukcijas, nepārtraukti tiek paaugstinātas prasības pret iekštelpu mikroklimatu, kā arī pieaugošais dažādu elektrisko un elektronisko ierīču izmantošanas apjoms var izraisīt ēku aukstuma slodzes palielināšanos. Ar saules enerğiju darbināma absorbcijas tipa dzesēšanas iekārta ir viens no risinājumiem kā efektīvi un videi draudzīgā veidā nosegt ēkas aukstuma slodzi, jo saules starojuma intensitāte praktiski sakrīt ar ēkas aukstuma slodzi. Darbā ir izvērtēti ar saules enerğiju darbināmu dzesēšanas iekārtu ekonomiskie un vides aspekti ēkām ar dažādiem iekšējiem siltuma ieguvumiem un ārējo norobežojošo konstrukciju parametriem. Lai sasniegtu saules enerǵijas dạ̧u vismaz $60 \%$, nepieciešamo saules kolektoru virsma ir robežās no 3 līdz $26 \mathrm{~m}^{2}$, savukārt īpatnējā saules kolektoru virsma ir apmēram $1.3 \mathrm{~m} / \mathrm{kW}$, ja absorbcijas tipa dzesēšanas iekārta generatoram tiek nodrošināts siltums ar konstantu temperatūru $65^{\circ} \mathrm{C}$. Aukstuma enerǵijas izmaksas ir robežās no 1.7 līdz $2.5 € / k W h$ atkarībā no ēkas iekšējiem situma ieguvumiem un ēkas ārējo norobežojošo konstrukciju energoefektivitātes rāēīājiem. Ar saules enerǵiju darbināma absorbcijas tipa dzesēšanas iekārtai ir pietiekoši liels $\mathrm{CO}_{2}$ samazinājuma potenciāls, tomēr neskatoties uz to, šādu dzesēšanas sistēmu izmaksas joprojām ir ekonomiski nepamatotas un nav konkurētspējīgas, ja salīdzina ar kompresijas tipa dzesēšanas iekārtām, kas tiek darbinātas ar elektroenerǵiju, t.sk. ņemot vērā elektroenerğijas tarifa paaugstināšanos jau tuvākajā nākotnē.

Дзинтарс Яунземс, Иварс Вейденбергс. Системы охлаждения малой мощности на основе солнечной энергии для климатических условий Латвии: экологические и экономические аспекты

В связи с тем, что современная архитектура зданий все чаще использует застекленный дизайн, постоянное увеличение требований к внутреннему микроклимату, а также повышение объема использования различных электротехнических и электронных устройств в зданиях может вызвать увеличения нагрузки охлаждения. Система охлаждения на основе солнечной энергии является эффективным и экологически чистым способом компенсации охлаждающей нагрузки здания, так как интенсивность солнечного излучения практически совпадает с нагрузкой на систему охлаждения. В работе рассмотрены экономические и экологические аспекты системы охлаждения на основе солнечной энергии в зданиях с различными внутренними и внешними параметрами. Для достижения по крайней мере $60 \%$ солнечной энергия, необходима поверхность солнечного коллектора от 3 до $26 \mathrm{~m}^{2}$ с удельной площадью поверхности солнечного коллектора около $1.3 \mathrm{~m} / \mathrm{kBT}$, если поглощение тепла генератором осуществляется при постоянной температуре $65^{\circ} \mathrm{C}$. Расходы на энергию в диапазоне от 1,7 до $2,5 € /$ кВтч в зависимости от внутренних источников энергии в здании. Системы охлаждения малой мощности на основе солнечной энергии имеют достаточно большие возможности для сокращения выбросов $\mathrm{CO}_{2}$, но несмотря на это, они все еще остаются экономически неоправданными и не являются конкурентоспособными по сравнению с традиционными системами, которые работают на электроэнергии. 